\title{
A Practical and Facile Synthesis of Azetidine Derivatives for Oral Carbapenem, L-084
}

\author{
Takeshi Isoda, ${ }^{*, a}$ Itsuki Yamamura, ${ }^{a}$ Satoshi Tamai, ${ }^{a}$ Toshio KumagaI, ${ }^{a}$ and Yoshimitsu Nagao ${ }^{b}$ \\ ${ }^{a}$ Medical Research Laboratories, Wyeth K.K.; Kashiwa-cho, Shiki, Saitama 353-8511, Japan: and ${ }^{b}$ Graduate School of \\ Pharmaceutical Sciences, The University of Tokushima; Sho-machi, Tokushima 770-8505, Japan.
}

Received June 14, 2006; accepted July 27, 2006; published online August 7, 2006

\begin{abstract}
An orally active carbapenem L-084, which exhibits high bioavailability in humans, has a 1-(1,3-thiazolin-2yl)azetidin-3-ylthio moiety at the $\mathrm{C}-2$ position of the $1 \beta$-methylcarbapenem skeleton. We established a practical and cost-effective synthesis of 3-mercapto-1-(1,3-thiazolin-2-yl)azetidine (1) for further scale-up production of L-084. This synthesis method entails an industry-oriented reaction of azetidine ring-closure to yield $N$-benzyl-3hydroxyazetidine (16), which is eventually converted to 1 via key intermediates, Bunte salts 19 and 20.
\end{abstract}

Key words L-084; carbapenem; azetidine; Bunte salt

Carbapenem antibiotics have long been in the spotlight because of their potent antimicrobial activity. The attention of both academic and industrial scientists has been attracted to the development of a new carbapenem for clinical use. Since imipenem $^{1)}$ was launched in 1987 by Merck Co., five additional compounds, panipenem, ${ }^{2)}$ meropenem, ${ }^{3)}$ biapenem, ${ }^{4)}$ ertapenem ${ }^{5}$ and doripenem, ${ }^{6}$ are now on the market. However, all these were developed for parenteral use, and the development of carbapenems for oral use has been expected for a long time. The title compound L- 084 is one of the hopeful candidates among recently reported oral carbapenems such as CS-834, ${ }^{7-12)} \mathrm{GV}-118819^{13-17)}$ and DZ-2640. ${ }^{18-27)} \mathrm{L}-084$, an ester-type prodrug of the active metabolite LJC11,036 (2), shows high bioavailability in humans, ${ }^{28)}$ and exhibits high antimicrobial activity against Gram-positive and Gram-negative bacteria. ${ }^{29)}$ The structural feature of L-084 is an achiral azetidine moiety at the $\mathrm{C}-2$ position of the $1 \beta$-methylcarbapenem skeleton, whereas CS-834 and DZ-2640 have a chiral pyrrolidine moiety as shown in Chart 1 . Synthesis of L-084 was carried out according to our reported procedure (Chart 2) ${ }^{28)}$ The condensation of enolphosphate $\mathbf{1 1}$ and thiol 1 afforded the $p$-nitrobenzyl (PNB) ester 12, which was then subjected to hydrogenolysis followed by esterification with pivaloyloxymethylchloride (POMCl) to give L-084.
In this paper, we describe a practical and facile synthesis of thiol $\mathbf{1}$ via Bunte salts $\mathbf{1 9}$ and $\mathbf{2 0}$ as key intermediates. This synthesis method for $\mathbf{1}$ is amenable to large-scale production.

Optimization of the Reaction for Azetidine Ring-Closure $^{30)}$ We have previously established the synthesis of 1 through 3-hydroxyazetidine hydrochloride (5) as a key intermediate. ${ }^{28)}$ Compound $\mathbf{5}$ was obtained in two steps including cyclization of $\mathrm{N}$-benzhydryl-3-chloro-2-hydroxypropylamine (3) and deprotection of the $N$-substituent according to the literature (Chart 2) ${ }^{31,32)}$ Although compound 5 has been well recognized as a useful building block for various bioactive molecules such as antimicrobial agent WQ-2743, ${ }^{33)}$ antiepileptic Dezinamide ${ }^{34)}$ and antihypertensive Azelnidipine, ${ }^{35}$ it has been suggested that the above two-step procedure for $\mathbf{5}$ was too expensive to adopt for large-scale production. Therefore, we decided to develop an alternative synthetic method for $\mathbf{5}$.

In the reaction of an azetidine ring-closure, one or more bulky substituents on the precursor were considered to be necessary to obtain the corresponding azetidine derivative effectively. A practical method for the scale-up production of derivatives of azetidinols bearing a less bulky substituent has not been developed yet. ${ }^{31,36-40)}$ Regarding the preparation of

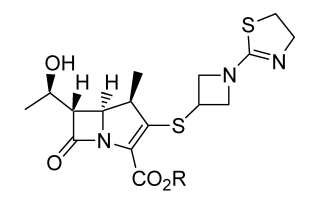

LJC11,036 (2): R = H L-084: $\mathrm{R}=\mathrm{CH}_{2} \mathrm{OCOC}\left(\mathrm{CH}_{3}\right)_{3}$

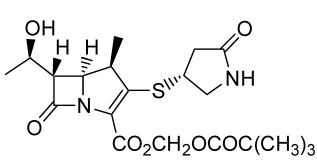

CS-834

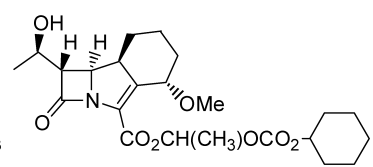

GV-118819

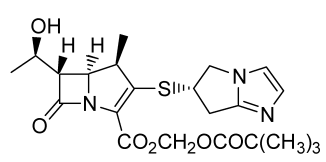

DZ-2640

Chart 1

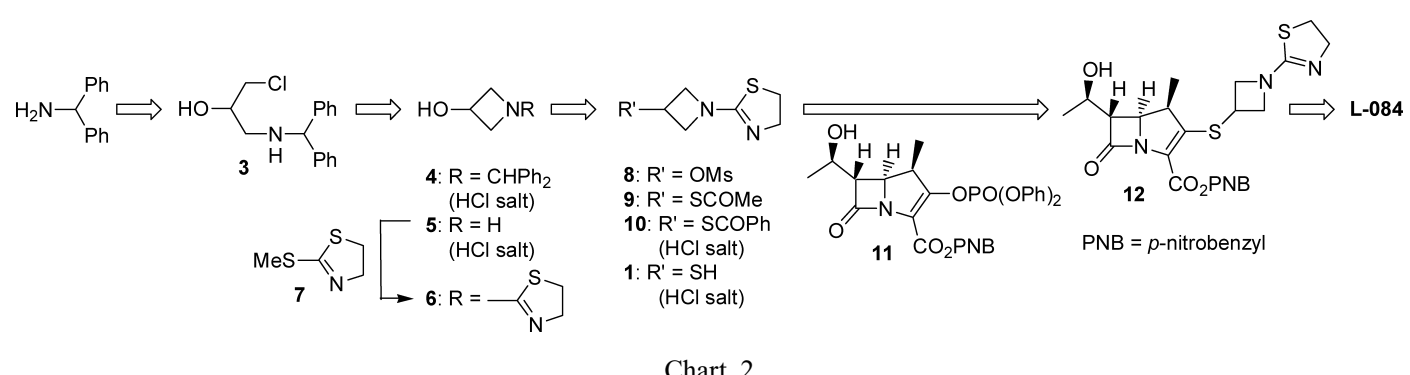

Chart 2 
a less bulky $N$-benzyl derivative, ${ }^{41,42)}$ only the $O$-protected compound $\mathbf{1 4}$ has been obtained by cyclization of $\mathbf{1 3}$ in low yield (Entry 1 in Table 1). In order to provide an industryoriented reaction of azetidine ring-closure, we focused on $N$ benzyl-3-chloro-2-hydroxypropylamine (15) as a precursor of the azetidine derivative $\mathbf{1 6}$, because $\mathbf{1 5}$ was prepared from benzylamine which was less expensive than benzhydrylamine. We initially checked out whether the benzylamino group attacked the $\mathrm{C}-1$ position of $\mathbf{1 5}$ under the same conditions of Entry 1, but the azetidine derivative 16 was not obtained at all (Entry 2 in Table 1). Because we had to avoid using a protecting reagent as much as we could from the cost point of view, we carefully carried out the optimization of reaction conditions to obtain $\mathbf{1 6}$ from $\mathbf{1 5}$ in the $10 \mathrm{mmol}$ scale experiments summarized in Table 1. The yield was found to be critically dependent on the solvent. The reaction proceeded in 2-propanol $(i-\mathrm{PrOH})$ or tert-butyl alcohol $(t$ $\mathrm{BuOH})$ in the presence of triethylamine $\left(\mathrm{Et}_{3} \mathrm{~N}\right)$ (Entries 3 and 4 in Table 1). Moreover, the yield of $\mathbf{1 6}$ dramatically increased in acetonitrile $(\mathrm{MeCN})$ when potassium hydrogencarbonate $\left(\mathrm{KHCO}_{3}\right)$ was added as a base (Entry 8 vs. 2 in Table 1). Finally, we could set the best reaction condition in which 16 was obtained in 90\% yield (Entry 10 in Table 1). We then examined the reaction on a $250 \mathrm{mmol}$ scale under the optimal conditions, but the yield of $\mathbf{1 6}$ decreased to $73 \%$. In searching for the reason of less reproducibility, we found that the particle size of $\mathrm{KHCO}_{3}$ affected the yield of this reaction (Table 2). Commercially available $\mathrm{KHCO}_{3}$ was considered not to be an appropriate reagent because of its wide distribution range of particle size, whereas sodium hydrogencarbonate $\left(\mathrm{NaHCO}_{3}\right)$ showed a narrow distribution range. We demonstrated that the large particles contained in the commercial reagent caused the decreasing of the yield. So we investigated the use of $\mathrm{NaHCO}_{3}$ instead of $\mathrm{KHCO}_{3}$ and confirmed that $\mathrm{NaHCO}_{3}$ was also a good reagent for this cyclization reaction (Entry 6 in Table 2). Further scale-up production was accomplished with excellent reproducibility (Entry 11 in Table 1). Through these experiments, we established the optimization of the reaction for azetidine ring-closure that was useful and applicable to the manufacturing of $\mathbf{1 6 .}$

Conversion of $\mathrm{OH}$ Group on Hydroxyazetidine Derivatives to SH Group ${ }^{43-47)}$ The introduction of an acylthio group using a metal acylthiolate is one of the general method for the synthesis of various thiols and related compounds. In the early stage of the development of L-084, thiol 1 was prepared from the acetylthio compound 9 according to the above method we previously reported. ${ }^{28)}$ As for a large-scale production, the oily compound 9 was considered not to be an appropriate precursor, and the second generation precursor, crystalline compound 10, was omitted due to the cost of a metal thiobenzoate (Chart 2). As a more convenient method for the preparation of $\mathbf{1}$, the introduction of a dithiosulfonate group was investigated. A variety type of alkylthiosulfate compounds, so-called Bunte salt, ${ }^{48)}$ were known to be readily prepared using economical sodium thiosulfate $\left(\mathrm{Na}_{2} \mathrm{~S}_{2} \mathrm{O}_{3}\right)$. However, probably due to its high polarity and poor solubility in organic solvents, there have been few applications utilizing this functionalized intermediate for a large-scale synthesis. Bunte salt 20, the precursor of $\mathbf{1}$, was successfully obtained from $N$-benzyl-3-hydroxyazetidine (16) in 4 steps. Mesylation of $\mathbf{1 6}$ followed by hydrogenolysis gave rise to 3methanesufonyloxyazetidine hydrochloride (18), which was easily converted to Bunte salt 19 in 52\% yield after stirring with $\mathrm{Na}_{2} \mathrm{~S}_{2} \mathrm{O}_{3}$ at $50{ }^{\circ} \mathrm{C}$ in methanol and water. The condensation of $\mathbf{1 9}$ and 2-methylthio-2-thiazoline (7) afforded $\mathbf{2 0}$ in $67 \%$ yield. Although the two sequential reactions from 18 to 20 both proceeded in moderate yield, we envisioned that the reactions could also proceed in a one-pot manner in a mixed

Table 2. Effect of the Particle Size of $\mathrm{KHCO}_{3}$ and $\mathrm{NaHCO}_{3}$

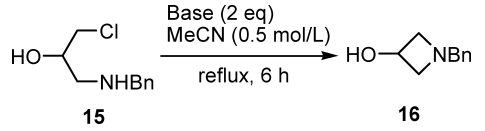

\begin{tabular}{ccccc}
\hline \hline Entry & Base & Particle size $(\mu \mathrm{m})$ & $\begin{array}{c}\text { Distribution } \\
\text { ratio }(\%)^{a)}\end{array}$ & $\begin{array}{c}\text { Reaction } \\
\text { yield }(\%)^{b)}\end{array}$ \\
\hline 1 & $\mathrm{KHCO}_{3}$ & $335-500$ & 53.5 & 58 \\
2 & $\mathrm{KHCO}_{3}$ & $250-355$ & 14.8 & 54 \\
3 & $\mathrm{KHCO}_{3}$ & $177-250$ & 13.0 & 98 \\
4 & $\mathrm{KHCO}_{3}$ & $150-177$ & 3.3 & 97 \\
5 & $\mathrm{KHCO}_{3}$ & $<150$ & 15.4 & 97 \\
6 & $\mathrm{NaHCO}_{3}$ & $<250$ & 96.9 & 98
\end{tabular}

a) Distribution ratio in commercially available materials. b) HPLC yield.

Table 1. Optimization of the Reaction Conditions for Azetidine Ring-Closure

\begin{tabular}{|c|c|c|c|c|c|c|}
\hline & & & $\begin{array}{l}=\mathrm{TMS} \\
=\mathrm{H}\end{array}$ & $\begin{array}{l}\text { 14: } R=T M S \\
\text { 16: } R=H\end{array}$ & & \\
\hline Entry & Substrate & Solvent & Conc. (mol/l) & Base (eq) & Product & Yield $(\%)^{a)}$ \\
\hline $1^{b)}$ & $13^{41)}$ & $\mathrm{MeCN}$ & 1.0 & $\mathrm{Et}_{3} \mathrm{~N}(3)$ & $14^{41)}$ & 38 \\
\hline 2 & 15 & $\mathrm{MeCN}$ & 1.0 & $\mathrm{Et}_{3} \mathrm{~N}(2)$ & 16 & N.R ${ }^{c)}$ \\
\hline 3 & 15 & $t-\mathrm{BuOH}$ & 1.0 & $\mathrm{Et}_{3} \mathrm{~N}(2)$ & 16 & 70 \\
\hline 4 & 15 & $i-\mathrm{PrOH}$ & 1.0 & $\mathrm{Et}_{3} \mathrm{~N}(2)$ & 16 & 60 \\
\hline 5 & 15 & $i-\mathrm{PrOH}$ & 1.0 & - & 16 & N.R. ${ }^{c)}$ \\
\hline 6 & 15 & $i-\mathrm{PrOH}$ & 1.0 & $\mathrm{KHCO}_{3}(2)$ & 16 & 40 \\
\hline 7 & 15 & $t-\mathrm{BuOH}$ & 1.0 & $\mathrm{KHCO}_{3}(2)$ & 16 & 57 \\
\hline 8 & 15 & $\mathrm{MeCN}$ & 1.0 & $\mathrm{KHCO}_{3}(2)$ & 16 & 58 \\
\hline 9 & 15 & $t-\mathrm{BuOH}$ & 0.5 & $\mathrm{KHCO}_{3}(2)$ & 16 & 85 \\
\hline 10 & 15 & $\mathrm{MeCN}$ & 0.5 & $\mathrm{KHCO}_{3}(2)$ & 16 & 90 \\
\hline $11^{d)}$ & 15 & $\mathrm{MeCN}$ & 0.5 & $\mathrm{NaHCO}_{3}(2)$ & 16 & 93 \\
\hline
\end{tabular}




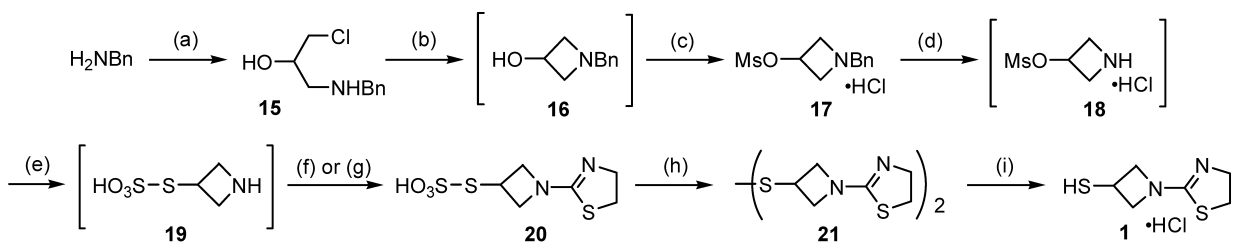

Reagents and conditions: (a) epichlorohydrin ( $0.95 \mathrm{eq}), \mathrm{H}_{2} \mathrm{O}, 15^{\circ} \mathrm{C}, 18 \mathrm{~h}, 89 \%$; (b) $\mathrm{NaHCO}_{3}(2.0 \mathrm{eq}), \mathrm{MeCN}$, reflux, $6.5 \mathrm{~h}$; (c) $\mathrm{MsCl}(1.1 \mathrm{eq})$, $\mathrm{Et}_{3} \mathrm{~N}\left(1.2 \mathrm{eq}\right.$ ), $\mathrm{MeCN}, 5^{\circ} \mathrm{C}, 7 \mathrm{~h}, 80 \%$ (2 steps); (d) $10 \% \mathrm{Pd}-\mathrm{C}, \mathrm{H}_{2} \mathrm{O}-\mathrm{MeOH}, \mathrm{H}_{2}(500 \mathrm{kPa}), 40^{\circ} \mathrm{C}, 24 \mathrm{~h}$; (e) $\mathrm{Na}_{2} \mathrm{~S}_{2} \mathrm{O}_{3}\left(1.0\right.$ eq), $\mathrm{H}_{2} \mathrm{O}-\mathrm{MeOH}, 50{ }^{\circ} \mathrm{C}$ $22 \mathrm{~h}$; (f) $\mathrm{Et}_{3} \mathrm{~N}$ (1.1 eq), chloroethylisothiocyanate (1.1 eq), $\mathrm{H}_{2} \mathrm{O}-\mathrm{MeOH}, 5^{\circ} \mathrm{C}, 0.5 \mathrm{~h}, 82 \%$ (3 steps); (g) 2-methylthio-2-thiazoline (1.1 eq), $\mathrm{H}_{2} \mathrm{O}$ $\mathrm{MeOH}$, reflux, $17 \mathrm{~h}, 42 \%$ (3 steps); (h) conc. $\mathrm{HCl}\left(5.0\right.$ eq), $55^{\circ} \mathrm{C}, 2 \mathrm{~h}$, then $\mathrm{H}_{2} \mathrm{O}_{2}$ (0.5 eq), $5{ }^{\circ} \mathrm{C}, 45 \mathrm{~min}, 93 \% ;(\mathrm{i}) \mathrm{Ph}_{3} \mathrm{P}(1.2 \mathrm{eq}), \mathrm{H}_{2} \mathrm{O}(2.0 \mathrm{eq})$, $\mathrm{HCl}$ in $\mathrm{MeOH}(2.5 \mathrm{eq}), \mathrm{MeCN}, \mathrm{rt}, 1.5 \mathrm{~h}, 93 \%$

Chart 3

solvent of methanol and water. After removal of the catalysts in the hydrogenolysis of $\mathbf{1 7}$, to the resulting solution of $\mathbf{1 8}$ was successively added $\mathrm{Na}_{2} \mathrm{~S}_{2} \mathrm{O}_{3}$ at $50^{\circ} \mathrm{C}$ and 7 under reflux. Unexpectedly, the overall yield of $\mathbf{2 0}$ in a one-pot manner was disappointingly low ( $42 \%$ yield from 17$)$. The reason of the low yield of $\mathbf{2 0}$ might be due to the severe reaction condition for the reaction of 19 with 7 (reflux, $17 \mathrm{~h}$ ). As shown in Chart 3, the use of chloroethylisothiocyanate instead of 7 enabled the reaction to proceed under mild conditions, and the overall yield from $\mathbf{1 7}$ to $\mathbf{2 0}$ was improved (82\% yield without isolation of 18 and $\mathbf{1 9}$ ).

Deprotection of $\mathbf{2 0}$ was carried out to obtain $\mathbf{1}$ by acid hydrolysis with conc. $\mathrm{HCl}^{47}{ }^{47}$ However, disulfide 21 concomitantly formed in $10 \%$ yield and could not be separated from crude 1 . In order to obtain pure 1 , we quitted studying the direct conversion and tried to add an oxidation step. The resulting crude 1 was treated with hydrogen peroxide to afford $\mathbf{2 1}$ in quantitative yield as illustrated in Chart 3. Reduction of 21 with triphenylphosphine also proceeded quantitatively, and thiol 1 was obtained in crystalline form, which was suitable for use in the synthesis of L-084.

\section{Conclusion}

We accomplished the synthesis of 3-mercapto-1-(1,3-thiazolin-2-yl)azetidine (1) in 52\% overall yield starting from benzylamine and epichlorohydrin. The new synthesis method not only increases the yield but also reduces the cost by half and is amenable to large-scale production. The reaction of azetidine ring-closure was achieved even in the case of a less bulky precursor $\mathbf{1 5}$ to afford $\mathbf{1 6}$ in quantitative yield. Compound 16 was eventually converted to $\mathbf{1}$ via zwitterionic Bunte salt 20 without isolation of $\mathbf{1 8}$ and 19.

\section{Experimental}

Melting points were determined using Yanagimoto micromelting point apparatus. NMR spectra were obtained on JEOL JNM-EX270 $(270 \mathrm{MHz})$ or Bruker Avance DPX400 (400 MHz) spectrometers using tetramethylsilane (TMS) or sodium 3-(trimethylsilyl)propionate- $d_{4}$ (TSP) as an internal standard. IR spectra were recorded on a JASCO FT-IR (VALOR-III) spectrometer. Mass spectra were recorded on JEOL JMS-DX300 or JMS-SX102A spectrometers. Elemental analysis was recorded on a Yanako CHN-Corder.

$\mathrm{N}$-Benzyl-3-chloro-2-hydroxypropylamine (15) To a solution of benzylamine $(138.8 \mathrm{~g}, 1.58 \mathrm{~mol})$ in water $(1.5 \mathrm{l})$ was added epichlorohydrin $(138.8 \mathrm{~g}, 1.50 \mathrm{~mol})$ at $5^{\circ} \mathrm{C}$, and the reaction mixture was stirred for $18 \mathrm{~h}$ at $15^{\circ} \mathrm{C}$. $n$-Hexane and $i$-PrOH $(1: 15,300 \mathrm{ml})$ were added to the reaction mixture, and the mixture was stirred for $2 \mathrm{~h}$ at $15^{\circ} \mathrm{C}$. The resulting precipitate was filtered and dried in vacuo to obtain $\mathbf{1 5}$ as colorless crystals $(265.2 \mathrm{~g}$, $89 \%), \mathrm{mp} 72-73{ }^{\circ} \mathrm{C} .{ }^{1} \mathrm{H}-\mathrm{NMR}\left(\mathrm{CDCl}_{3}\right) \delta: 2.72(1 \mathrm{H}, \mathrm{dd}, J=7.8,12.4 \mathrm{~Hz})$, $2.84(1 \mathrm{H}, \mathrm{dd}, J=4.1,12.4 \mathrm{~Hz}), 3.56(2 \mathrm{H}, \mathrm{d}, J=5.6 \mathrm{~Hz}), 3.81(2 \mathrm{H}, \mathrm{d}$, $J=2.0 \mathrm{~Hz}), 3.84-3.92(1 \mathrm{H}, \mathrm{m}), 7.23-7.37(5 \mathrm{H}, \mathrm{m}) . \mathrm{IR}(\mathrm{KBr}) \mathrm{cm}^{-1}: 3292$, 2899, 1453, 1346, 1252, 1072, 882. FAB-MS m/z: 200.0833 (Calcd for
$\mathrm{C}_{10} \mathrm{H}_{15} \mathrm{ClNO}:$ 200.0842). MS m/z: $200\left(\mathrm{M}^{+}+\mathrm{H}\right)$. Anal. Calcd for $\mathrm{C}_{10} \mathrm{H}_{14}$ CINO: C, $60.15 ; \mathrm{H}, 7.07 ; \mathrm{N}, 7.01$. Found: C, 60.12; H, 7.03; N, 6.98.

$\mathrm{N}$-Benzyl-3-hydroxyazetidine (16) (Entry 11 in Table 1) A mixture of $15(643.7 \mathrm{~g}, 3.22 \mathrm{~mol})$ and $\mathrm{NaHCO}_{3}(542.0 \mathrm{~g}, 6.45 \mathrm{~mol})$ in $\mathrm{MeCN}(6.4 \mathrm{l})$ was refluxed for $7 \mathrm{~h}$ and allowed to cool to room temperature. The reaction mixture was filtered, and the filtrate was evaporated to $600 \mathrm{~g}$. To the residue were added AcOEt $(300 \mathrm{ml})$ and heptane $(3200 \mathrm{ml})$, and the mixture was stirred for $1 \mathrm{~h}$ at room temperature. The resulting precipitate was filtered and dried in vacuo to obtain 16 as colorless crystals $(488.1 \mathrm{~g}, 93 \%), \mathrm{mp} 64-65^{\circ} \mathrm{C}$. ${ }^{1} \mathrm{H}-\mathrm{NMR}\left(\mathrm{CDCl}_{3}\right) \delta: 2.93-2.97(2 \mathrm{H}, \mathrm{m}), 3.59-3.63(4 \mathrm{H}, \mathrm{m}), 4.39-4.45$ $(1 \mathrm{H}, \mathrm{m}), 7.23-7.33(5 \mathrm{H}, \mathrm{m})$. IR $(\mathrm{KBr}) \mathrm{cm}^{-1}: 2837,1496,1476,1453$, 1342, 1174, 1083, 949. EI-MS m/z: 163.0997 (Calcd for $\mathrm{C}_{10} \mathrm{H}_{14} \mathrm{NO}$ : 163.1025). MS $m / z: 163\left(\mathrm{M}^{+}-\mathrm{Cl}\right)$

3-Benzoylthio-1-(1,3-thiazolin-2-yl)azetidine hydrochloride (10) To the warmed $\mathrm{AcO} n-\mathrm{Bu}(20 \mathrm{ml})$ were added 3-methanesulfonyloxy-1-(1,3thiazolin-2-yl)azetidine $(\mathbf{8})^{28)}(2.36 \mathrm{~g}, 10.0 \mathrm{mmol})$ and potassium thiobenzoate $(2.64 \mathrm{~g}, 15.0 \mathrm{mmol})$ under stirring. After being refluxed for $5.5 \mathrm{~h}$, the reaction mixture was cooled to room tempreture, and $5 \%$ aqueous $\mathrm{KHCO}_{3}$ $(7 \mathrm{ml})$ was added. The organic layer was separated, dried over $\mathrm{MgSO}_{4}$ and filtered. To the filtrate was added $4 \mathrm{~mol} / 1 \mathrm{HCl}$ in dioxane $(2.5 \mathrm{ml}, 10 \mathrm{mmol})$ at $15^{\circ} \mathrm{C}$, and the mixture was stirred for $1 \mathrm{~h}$ at $10^{\circ} \mathrm{C}$. The resulting precipitate was filtered and dried in vacuo to obtain $\mathbf{1 0}$ as colorless crystals $(2.70 \mathrm{~g}$, $86 \%), \mathrm{mp} 166-167^{\circ} \mathrm{C} .{ }^{1} \mathrm{H}-\mathrm{NMR}\left(\mathrm{CDCl}_{3}\right) \delta: 3.58(2 \mathrm{H}, \mathrm{t}, J=7.6 \mathrm{~Hz}), 4.15$ $(2 \mathrm{H}, \mathrm{t}, J=7.6 \mathrm{~Hz}), 4.20-4.25(1 \mathrm{H}, \mathrm{m}), 4.52-4.60(1 \mathrm{H}, \mathrm{m}), 4.81-4.87$ $(2 \mathrm{H}, \mathrm{m}), 5.23-5.31(1 \mathrm{H}, \mathrm{m}), 7.46-7.52(2 \mathrm{H}, \mathrm{m}), 7.60-7.67(1 \mathrm{H}, \mathrm{m})$, 7.88-7.91 (2H, m). IR (KBr) cm ${ }^{-1}: 3443,2980,1656,1446,1305,1208$, 912. FAB-MS $m / z$ : 279.0642 (Calcd for $\mathrm{C}_{13} \mathrm{H}_{15} \mathrm{~N}_{2} \mathrm{OS}_{2}: 279.0626$ ). MS $m / z$ : $279\left(\mathrm{M}^{+}-\mathrm{Cl}\right)$.

$\mathrm{N}$-Benzyl-3-methanesulfonyloxyazetidine hydrochloride (17) A mixture of $15(225 \mathrm{~g}, 1.13 \mathrm{~mol})$ and $\mathrm{NaHCO}_{3}(189.3 \mathrm{~g}, 2.26 \mathrm{~mol})$ in $\mathrm{MeCN}$ (2.251) was refluxed for $6.5 \mathrm{~h}$, and the solvent including water was then removed under reduced pressure to yield the residual solution of $\mathbf{1 6}(917 \mathrm{~g})$. After adding $\mathrm{MeCN}(1.241)$ and $\mathrm{Et}_{3} \mathrm{~N}(140.5 \mathrm{~g}, 1.40 \mathrm{~mol})$ to the solution, methanesulfonyl chloride $(140.0 \mathrm{~g}, 1.22 \mathrm{~mol})$ was added dropwise over $7 \mathrm{~h}$ under $5{ }^{\circ} \mathrm{C}$. The reaction was quenched with $13 \% \mathrm{HCl}$ in $\mathrm{MeCN}(359 \mathrm{~g}$, $1.3 \mathrm{~mol}$ ) under $5^{\circ} \mathrm{C}$, and the resulting precipitate was filtered and dried in vacuo to obtain 17 as colorless crystals $(245.6 \mathrm{~g}, 80 \%), \mathrm{mp} 137-138^{\circ} \mathrm{C}$. ${ }^{1} \mathrm{H}-\mathrm{NMR}\left(\mathrm{CD}_{3} \mathrm{OD}\right) \delta: 3.21(3 \mathrm{H}, \mathrm{s}), 4.33-4.65(4 \mathrm{H}, \mathrm{m}), 4.82(2 \mathrm{H}, \mathrm{s})$, $5.36-5.39(1 \mathrm{H}, \mathrm{m}), 7.48(5 \mathrm{H}, \mathrm{m})$. IR $(\mathrm{KBr}) \mathrm{cm}^{-1}: 2986,2507,2454,1351$, 1169. FAB-MS $m / z$ : 242.0849 (Calcd for $\mathrm{C}_{11} \mathrm{H}_{16} \mathrm{NO}_{3} \mathrm{~S}: 242.0851$ ). MS $m / z$ : $242\left(\mathrm{M}^{+}-\mathrm{Cl}\right)$. Anal. Calcd for $\mathrm{C}_{11} \mathrm{H}_{16} \mathrm{ClNO}_{3} \mathrm{~S}$ : $\mathrm{C}, 47.56 ; \mathrm{H}, 5.81 ; \mathrm{N}, 5.04$. Found: C, 47.66; H, 5.82; N, 5.03.

3-Methanesulfonyloxyazetidine hydrochloride (18) To a solution of $17(55.5 \mathrm{~g}, 200 \mathrm{mmol}), \mathrm{MeOH}(320 \mathrm{ml})$ and water $(80 \mathrm{ml})$ was added $10 \%$ $\mathrm{Pd}-\mathrm{C}(0.56 \mathrm{~g}$, dry reduced), and the mixture was stirred vigorously for $20 \mathrm{~h}$ under $400 \mathrm{kPa}$ pressure of hydrogen at room temperature. The catalyst was removed by filtration, and the filtrate was concentrated and triturated with MeOH-THF ( $15 \mathrm{ml}: 45 \mathrm{ml})$. The resulting precipitate was filtered and dried in vacuo to obtain 18 as colorless crystals $(35.8 \mathrm{~g}, 95 \%), \mathrm{mp} 106-107^{\circ} \mathrm{C}$ ${ }^{1} \mathrm{H}-\mathrm{NMR}\left(\mathrm{CD}_{3} \mathrm{OD}\right) \delta: 3.11(3 \mathrm{H}, \mathrm{s}), 4.28-4.32(2 \mathrm{H}, \mathrm{m}), 4.49-4.54(2 \mathrm{H}$, m), 5.41-5.47 (1H, m). IR (KBr) cm ${ }^{-1}: 2985,1575,1354,1174,1064$. FAB-MS $m / z: 152.0378$ (Calcd for $\mathrm{C}_{4} \mathrm{H}_{10} \mathrm{NO}_{3} \mathrm{~S}: 152.0381$ ). MS $m / z: 152$ $\left(\mathrm{M}^{+}-\mathrm{Cl}\right)$

Azetidin-3-ylthiosulfonic acid (19) To a suspension of $\mathbf{1 8}(7.5 \mathrm{~g}$, $40 \mathrm{mmol}), \mathrm{MeOH}(64 \mathrm{ml})$ and water $(16 \mathrm{ml})$ was added $\mathrm{Na}_{2} \mathrm{~S}_{2} \mathrm{O}_{3} \cdot 5 \mathrm{H}_{2} \mathrm{O}$ $(10.0 \mathrm{~g}, 40 \mathrm{mmol})$, and the mixture was stirred for $20 \mathrm{~h}$ at $50^{\circ} \mathrm{C}$ and then cooled to room temperature. The resulting precipitate was filtered and dried in vacuo to obtain 19 as colorless crystals $(3.52 \mathrm{~g}, 52 \%), \mathrm{mp} 225^{\circ} \mathrm{C}$ (dec.). 
${ }^{1} \mathrm{H}-\mathrm{NMR}\left(\mathrm{D}_{2} \mathrm{O}\right) \delta: 4.19-4.27(2 \mathrm{H}, \mathrm{m}), 4.44-4.54(3 \mathrm{H}, \mathrm{m}) . \mathrm{IR}(\mathrm{KBr})$ $\mathrm{cm}^{-1}:$ 3230, 1556, 1308, 1193, 1029. FAB-MS m/z: 169.9932 (Calcd for $\left.\mathrm{C}_{3} \mathrm{H}_{8} \mathrm{NO}_{3} \mathrm{~S}_{2}: 169.9946\right)$. MS m/z: $170\left(\mathrm{M}^{+}+\mathrm{H}\right)$. Anal. Calcd for $\mathrm{C}_{3} \mathrm{H}_{7} \mathrm{NO}_{3} \mathrm{~S}_{2}$ : C, $21.29 ; \mathrm{H}, 4.17 ; \mathrm{N}, 8.28$. Found: C, 21.25; H, 4.08; N, 8.12.

[1-(1,3-Thiazolin-2-yl)azetidin-3-yl]thiosulfonic Acid (20) a) To a suspension of $19(1.69 \mathrm{~g}, 10 \mathrm{mmol}), \mathrm{MeOH}(16 \mathrm{ml})$ and water $(4 \mathrm{ml})$ was added 2-methylthio-2-thiazoline $(1.60 \mathrm{~g}, 10 \mathrm{mmol})$, and the mixture was refluxed for $17 \mathrm{~h}$ and then cooled to room temperature. The resulting precipitate was filtered and dried in vacuo to obtain $\mathbf{2 0}$ as colorless crystals $(1.70 \mathrm{~g}$, $67 \%$ ), mp $218^{\circ} \mathrm{C}$ (dec.). ${ }^{1} \mathrm{H}-\mathrm{NMR}\left(\mathrm{CD}_{3} \mathrm{OD}\right) \delta: 3.65(2 \mathrm{H}, \mathrm{t}, J=7.5 \mathrm{~Hz}), 4.00$ $(2 \mathrm{H}, \mathrm{t}, J=7.5 \mathrm{~Hz}), 4.43-4.56(3 \mathrm{H}, \mathrm{m}), 4.70(2 \mathrm{H}, \mathrm{dd}, J=8.4,9.3 \mathrm{~Hz}) . \mathrm{IR}$ $(\mathrm{KBr}) \mathrm{cm}^{-1}: 3129,3041,1656,1453,1242,1205,1024$. FAB-MS $\mathrm{m} / \mathrm{z}$ : 254.9953 (Calcd for $\left.\mathrm{C}_{6} \mathrm{H}_{11} \mathrm{~N}_{2} \mathrm{O}_{3} \mathrm{~S}_{3}: 254.9932\right)$. MS $m / z: 255\left(\mathrm{M}^{+}+\mathrm{H}\right)$.

b) To a solution of $\mathbf{1 7}(2.22 \mathrm{~g}, 8 \mathrm{mmol}), \mathrm{MeOH}(6 \mathrm{ml})$ and water $(2 \mathrm{ml})$ was added $10 \% \mathrm{Pd}-\mathrm{C}(0.22 \mathrm{~g}$, dry reduced), and the mixture was stirred vigorously for $24 \mathrm{~h}$ under $500 \mathrm{kPa}$ pressure of hydrogen at $40^{\circ} \mathrm{C}$. The catalyst was removed by filtration, and to the filtrate was added $\mathrm{Na}_{2} \mathrm{~S}_{2} \mathrm{O}_{3} \cdot 5 \mathrm{H}_{2} \mathrm{O}$ $(1.98 \mathrm{~g}, 8 \mathrm{mmol})$. After stirring for $22 \mathrm{~h}$ at $50{ }^{\circ} \mathrm{C}$ and being cooled to $5^{\circ} \mathrm{C}$, $\mathrm{Et}_{3} \mathrm{~N}(1.23 \mathrm{ml}, 8.8 \mathrm{mmol})$ and chloroethylisothiocyanate $(1.07 \mathrm{~g}, 8.8 \mathrm{mmol})$ were added to the reaction mixture. The reaction mixture was stirred for $0.5 \mathrm{~h}$ and concentrated under reduced pressure to give crude $\mathbf{2 0}$. To a solution of $28 \% \mathrm{NaOMe}(1.53 \mathrm{~g}, 8 \mathrm{mmol})$ and $\mathrm{MeOH}(16 \mathrm{ml})$ was added crude 20 at room temperature with stirring, and the insoluble material was removed by filtration. To the filtrate were added $1.33 \mathrm{~mol} / 1 \mathrm{HCl}$ in $\mathrm{MeOH}$ $(7.4 \mathrm{ml}, 9.6 \mathrm{mmol})$ and IPA $(25 \mathrm{ml})$ at $5{ }^{\circ} \mathrm{C}$, and the mixture was stirred for $15 \mathrm{~min}$. The resulting precipitate was filtered and dried in vacuo to obtain $\mathbf{2 0}$ including 1 equivalent of $\mathrm{NaCl}$ as colorless crystals (gross $1.96 \mathrm{~g}, 85 \% \mathrm{pu}-$ rity, net $6.6 \mathrm{mmol}, 82 \%$ yield).

Bis[1-(1,3-thiazolin-2-yl)azetidin-3-yl] Disulfide (21) The mixture of 20 (gross $63.8 \mathrm{~g}, 51.8 \%$ purity, net $130 \mathrm{mmol}$ ) and conc. $\mathrm{HCl}(54.8 \mathrm{ml}$, $650 \mathrm{mmol}$ ) was stirred for $2 \mathrm{~h}$ at $55^{\circ} \mathrm{C}$. To the reaction mixture were added $\mathrm{MeOH}(27.4 \mathrm{ml})$ and water $(27.4 \mathrm{ml})$, and $\mathrm{KHCO}_{3}(104.1 \mathrm{~g}, 1.04 \mathrm{~mol})$ was then added to the mixture over $25 \mathrm{~min}$ at $5{ }^{\circ} \mathrm{C}$. After stirring for $1 \mathrm{~h}, 30 \%$ aqueous $\mathrm{H}_{2} \mathrm{O}_{2}(7.39 \mathrm{~g}, 65 \mathrm{mmol})$ was added to the mixture over $45 \mathrm{~min}$, and $\mathrm{Na}_{2} \mathrm{SO}_{3} \cdot 7 \mathrm{H}_{2} \mathrm{O}(3.28 \mathrm{~g}, 13 \mathrm{mmol})$ and water $(164 \mathrm{ml})$ were then added at $5{ }^{\circ} \mathrm{C}$. The reaction mixture was stirred for $1 \mathrm{~h}$ at room temperature. The resulting precipitate was filtered, washed successively with water and heptane and dried in vacuo to obtain $\mathbf{2 1}$ as colorless crystals (20.9 g, 93\%), mp 54$55^{\circ} \mathrm{C} .{ }^{1} \mathrm{H}-\mathrm{NMR}\left(\mathrm{CDCl}_{3}\right) \delta: 3.36(4 \mathrm{H}, \mathrm{t}, J=7.6 \mathrm{~Hz}), 3.88(2 \mathrm{H}, \mathrm{m}), 3.92(2 \mathrm{H}$, dd, $J=5.3,8.0 \mathrm{~Hz}), 3.94(2 \mathrm{H}, \mathrm{dd}, J=5.3,8.0 \mathrm{~Hz}), 4.02(4 \mathrm{H}, \mathrm{t}, J=7.6 \mathrm{~Hz})$, $4.30(4 \mathrm{H}, \mathrm{d}, J=8.0 \mathrm{~Hz})$. IR $(\mathrm{KBr}) \mathrm{cm}^{-1}: 1613,1344,1116,1005$. EI-MS $m / z: 347.0359$ (Calcd for $\mathrm{C}_{12} \mathrm{H}_{19} \mathrm{~N}_{4} \mathrm{~S}_{4}: 347.0493$ ). $\mathrm{MS} m / z: 347\left(\mathrm{M}^{+}+\mathrm{H}\right)$.

3-Mercapto-1-(1,3-thiazolin-2-yl)azetidine Hydrochloride (1) To a solution of $21(17.3 \mathrm{~g}, 50 \mathrm{mmol})$ in $\mathrm{MeCN}(25 \mathrm{ml})$ were added $\mathrm{Ph}_{3} \mathrm{P}(16.2 \mathrm{~g}$, $60 \mathrm{mmol})$, water $(1.92 \mathrm{~g}, 100 \mathrm{mmol})$ and $8 \mathrm{~mol} / 1 \mathrm{HCl}$ in $\mathrm{MeOH}(15.6 \mathrm{ml}$, $125 \mathrm{mmol}$ ), and the mixture was stirred for $1.5 \mathrm{~h}$ at room temperature. The reaction mixture was triturated with THF $(375 \mathrm{ml})$, and the resulting precipitate was filtered and dried in vacuo to obtain 1 as colorless crystals $(19.6 \mathrm{~g}$, 93\%). Physical and spectral properties are in accord with the disclosed data. ${ }^{28}$

\section{References}

1) Leanza W. J., Wildonger K. J., Miller T. W., Christensen B. G., J. Med. Chem., 22, 1435-1436 (1979).

2) Miyadera T., Sugimura Y., Hashimoto T., Tanaka T., Iino K., Shibata T., Sugawara S., J. Antibiot., 36, 1034-1039 (1983).

3) Sunagawa M., Matsumura H., Inoue T., Fukasawa M., Kato M., $J$. Antibiot., 43, 519-532 (1990).

4) Kumagai T., Tamai S., Abe T., Matsunaga H., Hayashi K., Kishi I., Shiro M., Nagao Y., J. Org. Chem., 63, 8145-8149 (1998).

5) Brands K. M. J., Jobson R. B., Conrad K. M., Williams J. M., Pipik B., Cameron M., Davies A. J., Houghton P. G., Ashwood M. S., Cottrell I. F., Reamer R. A., Kennedy D. J., Dolling U.-H., Reider P. J., J. Org. Chem., 67, 4771—4776 (2002).

6) Iso Y., Irie T., Iwaki T., Kii M., Sendo Y., Motokawa K., Nishitani Y., J. Antibiot., 49, 478- 484 (1996).

7) Miyauchi M., Endo R., Hisaoka M., Yasuda H., Kawamoto I., J. Antibiot., 50, 429-439 (1997).

8) Kobayashi S., Kobayashi K., Hirai K., Synlett, 1999, 909—912 (1999).

9) Mori M., Oida S., Chem. Pharm. Bull., 48, 126-130 (2000).

10) Kobayashi K., Fukuhara H., Takebayashi T., Kawamoto I., Jpn. Patent JP08119935 (1996) [Chem. Abstr., 125, 114394 (1996)].

11) Kawamoto I., Sugano O., Ishikawa K., Takebayashi T., Jpn. Patent JP08319271 (1996) [Chem. Abstr., 126, 144108 (1996)].
12) Maeda K., Inukai M., Jpn. Patent JP10165195 (1998) [Chem. Abstr. 129, 121709 (1998)].

13) Gaviraghi G., Eur. J. Med. Chem., 30 (Suppl.), 467s-478s (1995).

14) Rossi T., Biondi S., Contini S., Thomas R. J., Marchioro C., J. Am. Chem. Soc., 117, $9604-9605$ (1995).

15) Carlesso R., Holman S., Perboni A., Rossi T., WO9405666 (1994) [Chem. Abstr., 121, 57223 (1994)].

16) Perboni A., Sbampato G., WO9523149 (1995) [Chem. Abstr., 124, 8503 (1995)]

17) Rossi T., Andreotti D., Tedesco G., Tarsi L., Ratti E., Feriani A., Pizzi D. A., Gaviraghi G., Biondi S., Finizia G., WO9821210 (1998) [Chem. Abstr., 129, 41033 (1995)].

18) Tanaka M., Kato K., Hakusui H., Murakami Y., Sato K., Ito Y., Kawamoto K., Antimicrob. Agents Chemother, 44, 578-582 (2000).

19) Sato M., Takemura M., Higashi K., Soga T., Matsumoto H., Nishi T., Eur. Patent EP0210883 (1987) [Chem. Abstr., 106, 213640 (1987)]

20) Nishi T., Sugita K., Otsuka M., Hayano T., Jpn. Patent JP08253483 (1996) [Chem. Abstr., 126, 59806 (1996)].

21) Otsuka M., Nishi T., Hayano T., Jpn. Patent JP09241260 (1997) [Chem. Abstr., 127, 293224 (1997)].

22) Otsuka M., Nishi T., Jpn. Patent JP09323994 (1997) [Chem. Abstr., 128, 114824 (1997)].

23) Imura A., Ito M., Jpn. Patent JP10304893 (1998) [Chem. Abstr., 130, 24151 (1998)].

24) Akiba T., Saito T., Kanai K., WO9933830 (1999) [Chem. Abstr., 131, 102278 (1999)]

25) Akiba T., Saito T., Kanai K., Jpn. Patent JP11193284 (1999) [Chem. Abstr., 131, 87913 (1999)].

26) Akiba T., Saito T., Kobayashi Y., Jpn. Patent JP11315066 (1999) [Chem. Abstr., 131, 336937 (1999)].

27) Akiba T., Kobayashi Y. Saito T., Kanai K., Jpn. Patent JP11343281 (1999) [Chem. Abstr., 132, 22825 (1999)].

28) Isoda T., Ushirogochi H., Satoh K., Takasaki T., Yamamura I., Sato C., Mihira A., Abe T., Tamai S., Yamamoto S., Kumagai T., Nagao Y., J. Antibiot., 59, 241-247 (2006)

29) Hikida M., Itahashi K., Igarashi A., Shiba T., Kitamura M., Antimicrob. Agents Chemother., 43, 2010-2016 (1999).

30) Tamai S., Yamamura I., Jpn. Patent JP2000001474 (2000) [Chem. Abstr., 132, 49878 (1999)].

31) Chatterjee S. S., Triggle D. J., Chem. Commun., 1968, 93 (1968).

32) Katritzky A. R., Cundy D. J., Chen J., J. Heterocyclic Chem., 31, 271-275 (1994).

33) Yazaki A., Niino Y., Ohshita Y., Hirao Y., Amano H., Hayashi N., Kuramoto Y., Eur. Patent EP0911327 (1999) [Chem. Abstr., 126, 305587 (1999)].

34) Teng L. C., US Patent US4571393 (1986) [Chem. Abstr., 104, 224831 (1986)].

35) Koike H., Yoshimoto M., Nishino H., Eur. Patent EP0266922 (1988) [Chem. Abstr., 109, 149361 (1988)].

36) Gaertner V. R., Tetrahedron Lett., 1966, 4691-4694 (1966).

37) Gaj B. J., Moore D. R., Tetrahedron Lett., 1967, 2155-2157 (1967).

38) Okutani T., Kaneko T., Masuda K., Chem. Pharm. Bull., 22, 14901497 (1974).

39) Cromwell N. H., Phillips B., Chem. Rev., 79, 331-358 (1979).

40) Chang D., Feiten H. J., Engesser K., von Beilen J. B.,Witholt B., Li Z., Org. Lett., 4, 1859-1862 (2002).

41) Higgins R. H., Eaton Q. L., Worth L., Peterson M. V., J. Heterocyclic Chem., 24, 255-259 (1987).

42) Rearrangement of $\mathrm{N}$-benzyl-2,3-epoxyamine to obtain $\mathbf{1 6}$ in moderate yield was recently reported. See: Oh C. H., Rhim C. Y., You C. H., Cho J. R., Synthetic Commun., 33, 4297-4302 (2003).

43) Isoda T., Tamai S., Kumagai T., Nagao Y., Heterocycles, 68, 18211824 (2006).

44) Isoda T., Yamamura I., Jpn. Patent JP2000355592 (2000) [Chem. Abstr., 134, 56662 (2000)].

45) Isoda T., Yamamura I., Jpn. Patent JP2001226346 (2001) [Chem. Abstr., 135, 182367 (2001)].

46) Isoda T., Yamamura I., Jpn. Patent JP2002003490 (2002) [Chem. Abstr., 136, 69804 (2002)].

47) Isoda T., Yamamura I., Jpn. Patent JP2002003491 (2002) [Chem. Abstr., 136, 69806 (2002)].

48) Bunte H., Chem. Ber., 7, 646-648 (1874).

49) El-Hewehi V. Z., Taeger E., J. Prakt. Chem., 4, 191-195 (1958). 